\title{
What is a Rhetoric of Death? End-of-Life Decision- Making at a Psychiatric Hospital ${ }^{1}$
}

\author{
Judy Segal \\ University of British Columbia
}

Le présent article est le fruit d'une recherche en collaboration dans un hôpital psychiatrique. Cette recherche visait l'élaboration d'un protocole en vue de définir des directives pour l'assistance à des personnes gravement malades et mentalement inaptes dans leurs derniers jours. Appelée à agir comme rhétoricienne, je me suis servie d'entrevues entre les membres de la famille et l'équipe de professionnels, sur vidéos ou en transcription. J'ai exploré des questions du type : "comment les gens s'informent-ils de la mort?", «comment les patients et les membres de leur famille s'expriment-ils au sujet de mandat à confier?", "quelle est la rhétorique d'une prise de décisions par consensus? " "lorsque que les médecins et les membres de la famille traitent de vie et de mort, qui persuade qui, et de quoi, et quels sont les moyens de persuasion utilisés".

Je présente ici mes observations et une première analyse. Mon article contient aussi des réflexions générales sur l'analyse rhétorique et la rhétorique de la science au Canada.

\section{Introduction}

\section{On Rhetoric of Science in Canada}

While much can be claimed about the various functions the study of rhetoric of science might serve (see, for example, Fuller 1993 and the essays in Gross and Keith, 1997), I wish to make the general claim that the project of rhetoric of science in Canada includes a well-developed sense of the usefulness of applied rhetorical research, including the notion that rhetorical study could have, in some relatively centralized scheme of things, an ameliorative effect. 
One field of contemporary rhetorical research is "rhetoric of the professions," including the scientific and social scientific professions, and this field has asserted itself especially in Canada in the last ten years, in the work, for example of Vipond (1993), Schryer (1993), Paré (1993), and Segal (1993). In such research, rhetoricians of science are not easily distinguishable from genre rhetoricians, and, sometimes, a thesis in the text or subtext of their work is that genre study can have implications for professional social action. Paré's work in social science is a good case in point. While Paré is not trying to "improve" the social workers whose professional genres he studies, he is attuned to the possible practical implications of his research (see Segal, Paré, Brent, \& Vipond, 1998). This blurring of categories of rhetorical study rehearses a trend among certain American scholars/researchers. Charles Bazerman, Carolyn Miller, and Carol Berkenkotter, for example, all work in rhetoric of science by working in professional genres. ${ }^{2}$ Another trend in American rhetoric of science - which I might call, after Gross and Keith, "rhetorical hermeneutics in the age of science" allies itself more to French (e.g., Bruno Latour), British (e.g., Harry Collins), and American (e.g., Steven Shapin) science studies. This latter rhetoric of science has had relatively little play in Canada, where science studies and Science and Technology Studies (STS) have been the province of sociologists, historians, and philosophers of science, but not, particularly, rhetoricians. Of course, there are Canadian rhetoricians who are science studies scholars (e.g., Harris, 1990, 1991, 1993), and rhetorically astute sociologists (e.g., Overington, 1977) and historians of science (e.g., Stewart, 1992). But it is interesting to consider why the genre/social action profile in Canadian rhetoric of science is relatively high.

One reason that Canadian rhetoricians are drawn to socially situated research is, I think, rhetorical optimism - an optimism that comes from Canada's relative smallness, centrism, and liberalism. Recent events in health research funding speak to this Canadian condition. In a federal budget announcement in February 1999, Health Minister Alan Rock announced the creation of Canadian Institutes of Health Research (CIHR), allocating new major funding to health research, including a portion of the budget for spending through the Social Science and Humanities Research Council (SSHRC). In initial funding, the greatest share of research dollars is to be spent in connection with the mechanisms of the Medical Research Council, with lesser and equal portions going to SSHRC and to the National Science and Engineering Research Council (NSERC). So health research became, with the announcement of the creation of Institutes, a coordinated transdisciplinary enterprise with the overarching goal of improving the health of Canadians. ${ }^{3}$ The keyword for new funding initiatives - the Research Institutes themselves are being designed at this moment (July 1999), with tri-council input — is integrativeness. The point for rhetorical 
research is this: in this new climate of health research spending in Canada, a humanist is an imaginable member on a research team on, for example, mental illness - a team that might include as well, a biochemist, a psychiatrist, a neuroendocrinologist, and a medical anthropologist. The humanist on any number of health research teams might certainly be a rhetorician. That is, while there is always a case to be made for basic research in a discipline, there is some incentive in Canada, not just in funding, but in the promise of making a difference, to do situated, applied research. ${ }^{4}$

\section{On This Project}

In the remainder of this essay, I describe a project in which I worked as a rhetorician on a multidisciplinary research team, coming, in the course of the project, to understand something about the usefulness of a rhetorical perspective in a clinical setting. The project began at Riverview Hospital in Port Coquitlam, British Columbia, early in 1998 and is drawing to a close now, approximately a year and a half later. The project is not related to an activity of Canadian Institutes of Health Research; however, it speaks exactly to the spirit in CIHR of integrated research involving the humanities and social sciences in areas traditionally held exclusively by medicine.

The Riverview project raises a number of questions of interest to scholars, clinicians, patients, families, and the society of which they are a part: "What counts as an acceptable quality of life?" "When should a life be over?" "Who decides when a life should be over - and how?" and "What is personhood?" Thus, it participates in questions already raised in a growing literature, much of it in bioethics (see, for example, Ryan, 1996 and Molloy, 1993). It also raises a number of questions of special interest to rhetoricians: "How do people talk about death and dying?" 5 "How do patients and their family members express agency?" "What is a rhetoric of consensual decision-making?" "When clinicians and family members speak of life and death, who is persuading whom of what, and what are the means of persuasion?"

And this: "What has the second set of questions to do with the first?"

\section{The Riverview Project}

Riverview is a psychiatric hospital providing tertiary (specialized) care. The current project involves Riverview residents, many of whom are in advanced stages of dementia; they are, owing to a number of conditions, including Alzheimer's disease, unable to participate in decision-making about their own lives and deaths. The purpose of the project is to improve the process of establishing and implementing Advance Directives for these residents. Ward staff and family members are engaged with a clinical team (psychologist, physician, nurse, social worker, chaplain) in a protocol of consensual decision-making. Advance Directives (AD) pertain to two sorts of de- 
cisions: the first concerns resuscitation orders (e.g., in the event of cardiac arrest, should the patient be resuscitated?); the second concerns "levels of intervention" (four levels, in this case, ranging from interventions aimed at providing palliative care to the greatest possible interventions aimed at prolonging life).

Family members of qualifying residents are contacted, by letter and phone, and invited to participate in the project. The objectives of the study and the procedures of consensual decision-making are described; resuscitation orders and levels of intervention are explained. Family members, who might, in addition, be well acquainted with hospital staff, are asked to meet with the team psychologist (also the project's principal investigator) before the decision-making interview. The interview itself takes approximately one hour and involves one or more family members and all five members of the clinical team. Following the interview, a summary of the discussion is sent to family members for signature; family members may, of course, change the Advance Directive at any time.

Several elements of the AD interview have been relatively constant over the course of the project. One common element is the shape of the interview itself. Interviews begin, with introductions and formalities, and after family questions and comments have been invited, with a report by the physician on the medical and psychiatric condition of the patient. The nursing perspective - with a focus on quality of life issues - comes later in the interviews. And certain points and approaches are routine. These are illustrated below with examples from the transcripts. ${ }^{6}$ (See Note 6 for a legend of the participants in the transcripts.)

\section{The structure of the interview is described:}

\section{Transcript 5:}

SW So the way we're going to do this meeting we'll keep it informal but we have a bit of a structure. MD is going to give us the most current medical and psychiatric condition of R. N will talk about sort of the behaviours on the ward, abilities, deficits, sort of quality of life matters that are important to this decision. P will take us through the form that we'll be completing as a result of this meeting and go through it step by step with you as he's probably already done. A little bit. And $\mathrm{C}$ and $\mathrm{I}$ are here to ... $\mathrm{C}$ is here for I guess spiritual questions in a matter like this. And I'm here just to sort of facilitate and make sure that you're understanding and that we're all understanding what the essence of what we're discussing here. (pp. 2-3) 
2. Family members, having been encouraged to do so, draw on knowledge of what the patient would have wanted for end-of-life care:

\section{Transcript 7:}

FM ... In 1990, $\mathrm{R}$ had the pacemaker put in him. He was very ill with the heart problem. And they rushed him to [the hospital] and they installed the pacemaker. And when he woke he said, why did you bother doing that to me, he said, I'm eighty years old. And he said, these old bones just don't want to carry me no further. And there's more room for other people in this world. So he felt in his mind that, even at that time, that prolonging his life wasn't necessary. So it's his wishes as well. (p. 9)

\section{Transcript 1:}

FM2 He said specifically, one example he gave me specifically, was he talked about ... if I get pneumonia, let, I mean give me aspirin to keep me comfortable ..., but do not treat the disease. Do not treat the pneumonia. Let me die. Specifically he said those words to me. And that was the example that he gave me at that point in time. (p. 8)

Where there is no clear knowledge of what the patient would have wanted, family members are urged to empathize with the patient:

\section{Transcript 6:}

MD One way of making it easier to think of is put yourself in her position ... and where you can make a decision, what you would want. (p. 9)

\section{Transcript 5:}

SW ... and we're trying to put ourselves in [your husband's] shoes if he was, if he was well enough to tell us what would he want to say in this situation ... (p. 1) 


\section{Family members are reminded that the decision-making is consensual (with the clinical team) and that hospital staff will not carry out any advice with which they do not feel comfortable:}

\section{Transcript 6:}

$\mathrm{P} \quad$ Let me also add that in this process of discussion and giving you different options, we wouldn't carry out and follow an instruction which we didn't feel we were comfortable with. So we're working within a range here that we feel comfortable with, with whatever you decide. And the options of somebody ... If a family member came and gave us options which we felt were totally unreasonable, we would say that. We would not go along with it. (p. 12)

\section{The Rhetorician's Role in the Project}

I was invited to participate in the study as a specialist in issues of language and communication. I had met members of the Riverview staff some months before when I was invited, through contact with the person who became the project's principal investigator, to speak on problems of differences between personal and institutional discourses of death and dying, a topic of my current research. ${ }^{7}$

I was, in general, understood as someone who was interested in helping to improve communication between family members and professionals - although I saw myself also as taking a step further back, being interested not only in facilitating the $\mathrm{AD}$ interview but also in understanding it. That is, I asked not only "how can I help make this go more smoothly?" but also "what is this process?" In fact, the team as a whole was extremely conscientious about matters of clarity - and especially clarity of terminology - as they considered their own discourse in the Advance Directive interviews. The social worker, for example, regularly made a point of welcoming questions of clarification:

\section{Transcript 1:}

SW So I want to make sure that you're always comfortable with the words that we're using too. If at any time you hear us say something that doesn't sound familiar ... please tell us. Because we tend to talk in hospital language sometimes not in real world language. Common language. And please ask questions, anything you need to know. (p. 3)

And family members did request clarification, thus: 


\section{Transcript 7:}

MD The other thing is that he had an upper GI bleed in the past too.

FM Which is?

Moreover, team members would act on the family members' behalf to seek clarification:

\section{Transcript 5:}

MD So in terms of his medical problems .... He's got ... interstitial lung disease ... and basically you know there's been no change in terms of his presentation.

$\mathrm{P} \quad$ What does this mean, interstitial lung disease?

\section{Method}

\section{On Rhetorical Analysis Itself}

I have argued elsewhere that rhetorical analysis does not proceed by algorithm but may be defined, methodologically, more generally, as analysis performed by a rhetorical critic; it is reading informed by an understanding of rhetorical principles and performed for some purpose. ${ }^{8}$ The rhetorical critic works from a rhetorical subjectivity, which is constructed in the terms and history of a tradition that the critic takes as "tacit knowledge" (to borrow a term from Polanyi [1958]) — a tradition from Sophism to postmodernism - and, like rhetoric itself, rhetorical criticism may best be considered not for what it is but for what it does (to borrow a phrase from Corbett [1969]). Fuller (1993), for example, talks about "the distinctiveness of rhetoric as a practice that has periodically interrupted, as well as represented, the normal flow of discourse" (xii).

This is Fuller later (1997) on rhetoric of science:

The more that rhetoric of science looks like classical rhetoric, the less exciting its interpretations seem... Yet, the more that rhetoric of science strays from classical sources, and the more provocative its readings become, the more interchangeable its methods seem with those used by sociologists and critical theorists. (p. 279) 
Fuller captures here a definitional problem of rhetorical criticism: it risks being perceived as something quite narrow, and possibly dated, but may otherwise be little distinguishable not only from other critical programs but also from other critical disciplines. Perhaps it is helpful then, especially to understanding the project of rhetoric of science, taking Fuller's two passages together, to say that two identifying features of rhetorical criticism are its informing theory - rhetorical critics have, notwithstanding certain diverging inclinations, some common body of literature - and its motive.

What is remarkable about the motive of rhetorical critics is how often rhetorical criticism seems to tend to deliberative engagement. For example, Roderick Hart (1994) writes:

Criticism is not something I do; it is something I am. I am a critic because I often do not like the language my contemporaries speak nor the policy opinions they endorse. I am a critic because I feel that rhetoric should move a society forward rather than backward, that it should open and not close the public sphere, that it should make people generous and not craven. I am a critic, ultimately, because I am a citizen. (p. 72)

Philip Wander, among the earliest rhetoric-of-science advocates, believes that rhetorical criticism is itself a kind of exhortation, a contribution to the public discourse, which is its subject. ${ }^{9}$ Barbara Warnick writes that critics like Wander seek to enter texts polemically. The "advocate critic," she says, seeks "to persuade, to change readers' perspectives through the process of criticism" (p. 233).

It is not that rhetorical criticism is a social action criticism, but rhetorical criticism does have an element, or a strand, of motive in the fray. My claims here about rhetoric, then, are that it is not unified; it is not algorithmic; it takes its variety from rhetorical theory; and it takes its motive from situation. (In Canada, rhetoric of science has special reasons for tending to engagement and social action.) So, I could produce an account of the questions I posed to the Riverview transcripts, but I could not, except by some back-formation, say exactly why I posed these and not others in the first instance. They are utterly simple questions from a rhetorical perspective and they embody rhetorical theory and rhetorical motive. While another rhetorical analyst might not follow precisely the same course I have, another analyst should be able to scrutinize my observations and find them to be consistent with a rhetorical world view.

My initial study of the transcripts was organized according to questions most closely associated to a Burkean rhetorical perspective - questions about scene and purpose and about terms themselves ${ }^{10}$ : What is the effect of the institutional context in 
which the AD conversation is taking place? What is the purpose of the interviews? What do the terms in use mean to each of the participants? Following are my initial observations."

\section{Rhetorical Findings from the Study of Transcripts}

\section{The placement of the physician's report in the initial position in the interview itself has rhetorical force.}

While issues of quality of life are at the centre of $\mathrm{AD}$ decision-making, the interview routinely begins with medical rather than lifestyle concerns. Of course, the two are related; however, beginning with the medical report gives a particular importance to medical information in decision-making. The place of the medical report in the structure of the interview also underlines the expert/non-expert division - or perhaps privileges one kind of expertise over another. Family members clearly are aware of their own limitations in conversations about the end of life.

\section{Transcript 3:}

FM Well when you talk about the vascular [dementia] does that mean she's had some of these small strokes or not? ... The reason I wondered was that one time when she was living with me she started to get up off the chesterfield ... and she was dizzy ... it seemed as though she might have had a small stroke. What I know [sic]. Not being a doctor or a nurse or anything else. But it gave me that feeling that maybe that's what was happening. (pp. 3-4)

\section{Transcript 7:}

FM I think that move, that short move up the hill [to another hospital ward], affected him. So taking him out of hospital, he would not survive. In my opinion. And I'm, certainly, I'm not a doctor. Or anything. But, yeah. (p. 11)

A further significant feature of the physician's initial medical account is its monologic quality. That is, since consensual decision-making is necessarily a dialogic process, the medical account itself is generically out of phase with the interview. The medical account does count as a conversational turn - though an inordinately long one (the MD is receptive to interruptions and requests for information and clarification, but clearly has the floor for several minutes once the meeting is underway). 


\section{The terms that family members bring to an $A D$ interview can be} terms that are cultural conventions for end-of-life talk, and, for that reason, unexamined.

It is certainly the case that some terms circulate in a culture for end-of-life talk. The same terms circulate in an AD interview, and themselves play a role in decisionmaking.

\section{Transcript 4:}

FM We don't believe that she should be kept on a machine just to be kept alive and be a vegetable. (p. 6)

\section{Transcript 5:}

FM Oh if he could talk, he would say, he'd be the first one to pull the plug. I know that. (p. 21)

\section{Transcript 3:}

FM It's this keeping a person alive with tubes and things just for the sake of keeping them alive, no. I have never wanted that. Wouldn't want it for myself so why would I want it for anybody else? (p. 8)

In some cases, as illustrated below, team members push at the terms, asking family members to visit their assumptions; however, phrases like "pull the plug" and "die in peace" (Transcript 4) were not interrogated.

\section{Transcript 1:}

P [W] hat did you understand by code blue when you initially instructed us that you didn't want a code blue? (p. 7)

\section{Transcript 7:}

$\mathrm{P} \quad$ And that part of the discussion is really, to clarify what people mean by palliative care when they say that. That's why we're going through this to really ensure that what we're saying is the same as what you're saying and the same as what [other FM] is saying. (p. 12) 


\section{The ways in which choices are framed and articulated by clinical team members may seem to foreclose some options.}

In general, the choice is presented to family members in the AD interview as a version of this: "to decide are we going to intervene and treat the person or allow nature to take its course." (Transcript 1, p. 3) That is, the decision not to treat is portrayed as "natural"; conversely, the decision to treat is usually termed "aggressive":

\section{Transcript 1:}

P So the level one, the goal would be primarily and almost only to keep the person comfortable, ... not do anything to stop nature from taking its course.... The second level would be a little more aggressive than that. We'd say — and each level up includes everything you would do below, so we'd, naturally we'd keep the person comfortable, pain-free, under all circumstances anyway. (p. 3)

\section{Transcript 4:}

MD We want to try to establish something with your help trying to figure out what $\mathrm{R}$ would have wanted for herself in the future should she become critically ill. What she would want the doctors here and the medical staff to do. How to treat her more generally - aggressively treat an illness or back off a little bit and let nature take its course. (p. 1)

\section{Transcript 5:}

MD We should differentiate transferring within the hospital, like to the medical unit, where they can do more aggressive interventions than we can do on the ward, and then transferring out of the hospital, which in a way is, you know it can be, it can be necessary for even more aggressive treatment. (p. 14)

While it is clear that the clinical team means to leave decisions in the hands of family members, providing them with information, it is also true that the choice is charged rhetorically, and that some terms - like "natural" — are eulogistic, while others, like "aggressive," are dyslogistic:

\section{Transcript 6:}


P ... The question is do we feel, if something natural occurred, it's time now to let nature take its course or, if we fairly without a lot of intrusion return her to the current level of function that she's now at, should we do that?

FM Well as far as an antibiotic or penicillin, say an injection of penicillin that was to clear up some infection and that would work? Certainly we would give her that. We wouldn't just let her - That part, yes.

P Right so the things we can do on the ward (FM:// Umm hmm exactly yes.) At least we should try and do that. Okay ... What about if it required a transfer to our medical surgery ward which would be where she'd have to be treated more aggressively with certain intravenous injections or intravenous .... (pp. 10-1)

The clinical team members by their own report do not intend to lead the decision - and indeed they do need to press for specificity, precision, clarification, since their purpose is to have directions that will become orders on a patient's chart. My observation is an observation about the valence of terms. Although "aggressive" has like "heroic" - a particular meaning in a medical context, it is also the case that the term carries weight, even metaphoric weight, in use.

Furthermore, family members do, in many cases, seem to wish to comply with what they assume are the wishes of medical professionals; they may seek the approval of professionals and make assertions with respect to end-of-life care that will find approval:

\section{Transcript 1:}

FM Not that I think R is going to get better. You know there's some people keep saying to me, don't you want him to get better, of course I do but I mean, I have to face reality....

Moreover, professionals, sensing the need for approval, may offer it readily:

\section{Transcript 1:}

FM1 I know Mom this is an emotional thing and it's very emotional for me ... l'd like my dad to go.

$\mathrm{N}$ I respect that. I respect that. (p.10)

Some family members respond to the importance of the medical element in the 
occasion by adopting a medical-like language themselves:

\section{Transcript 1:}

FM1 talks about "what [father's] time was to live ...

FM2 inserts, "Expected life span."

FM1 ... [he] absolutely does not believe in suicide.

FM2 Or assisted, or assisted suicide.... I know that it's, there's part of the disease I understand is psychotic and it can also be ... a suicidal tendency are a part of it. (p. 9)

\section{Family members make moves to claim authority in the rhetorical situation.}

Family members assert authority primarily in two ways: first, by their knowledge of the patient and especially knowledge of his or her current institutional life (rhetorically, an argument from ethos works here - that is, the family member who visits the patient regularly or speaks to him or her frequently on the telephone is one who is in a good position to state preferences) and by their assumption of the ability to praise or blame - they usually praise - hospital staff (for example, Transcript 7 , p. 10: FM, "I think it's a good, good system you're devising"). Sometimes the two claims to authority are merged:

\section{Transcript 3:}

FM [My sister] really responded to music ... you know what I mean. Um, and I don't know. I'm not saying - I'm not blaming anybody for it, don't get me wrong in that, but um, I've always felt that it would have done a lot for her earlier.... (p. 10)

\section{Transcript 4:}

FM I hope you understand l'm not complaining about this here, I'm just bringing it, make you, make you aware of it .... Well myself personally I know she's in the best of care ... because I talk to nurses over here and uh we pretty well leave it to the doctors here and to the nurses because their judgement be a lot better. 
And we realize that the mood she is at times, it makes it very hard for the nurses over here. Because physically she is a strong woman. I know because I've had to manhandle her. (p. 5)

\section{While the primary goal of the AD meeting is to arrive at decisions} regarding end-of-life care, it is also the case that an important purpose of the meeting is to provide a context within which decisions already made can be aired and made less painful.

Providing support to family members is certainly an element of the AD project and viewing the videotapes and reading the transcripts does show an interesting movement between the patient (absent) and family member(s) as the centre of attention. In a sense, while the physician and nurse take the patient as their primary focus, the psychologist, social worker, and chaplain take the family member(s) as their primary focus. When, as in the case of one interview, the resident patient is a schizophrenic who has been institutionalized for forty years and now has dementia, what family members need is not so much a way of making decisions about the end of life but a way of coping with decisions that are, sadly, too easy to make:

\section{Transcript 6:}

FM ... the way she's deteriorated I mean she I can see it I mean she's uh incapable of, you know, doing her own bodily functions and uh as you say the dementia started so I mean (.) it's (.) I know it sounds maybe hard or cruel but if

MD No I mean it's not a matter of there was a light at the end of the tunnel I would say .... No if you think that what she would want then it's not cruel .... (p. 12)

An important element of the interview, then, is to deal with, for example, feelings of guilt that family members might have having decided that they would want a DNR order and the lowest level of intervention:

\section{Transcript 5:}

FM1 ... Like it's hard. (P://It is hard.) It's still that guilt. I would agree I'm really laying guilt on myself. So that's why I'm afraid to mention too much of that I don't want [wife of R] to feel that. Because I'm glad she feels good. But I'm I'm ...

$\mathrm{N}$ But she knows him the best. 
FM1 She does.

N She knows him the best.

$\mathrm{P} \quad$ Well, guilt is also -

$\mathrm{N}$ And if that's his wish, then that's his wish.

P Guilt is also in two directions. One is prolonging suffering.

FM1 Yeah I know.

P You know as well. (FM2://That's the part that ...) And that's what I'm hearing for somebody -

FM1 But you see I'm, I'm at the other end too where my dad, should be, have died by now. And I'm feeling guilty and wish he would almost.... (p. 22)

\section{Reporting Rhetorical Findings to Members of the Clinical Team}

\section{On Clinical Implications of Rhetorical Findings}

It will have been clear from the fragments of transcripts supplied that the goal of members of the clinical team is carefully to arrive at guidelines for care of resident patients. Their rhetoric en route was more my concern than theirs. I have, however, discussed my observations with team members; our purpose then, together, was to consider any practical, clinical implications of my findings.

Some points can be made about my reporting process itself. The role of the outsider-researcher is problematic (I am on the research team but not the clinical team, and the one person on any team who does not work at the hospital). (See Segal, Paré, Brent, \& Vipond, 1998.) And the question of amelioration in the context of research is tricky. Still, while I could position myself as someone who would just describe the rhetoric of the $\mathrm{AD}$ meeting, and not evaluate or judge, it is also the case that the clinical team wanted some value for my participation; they hoped there would be something in my report that could be useful to them in reflecting on their own procedures. 
I had attended some working meetings at the hospital over the course of the project, especially early on. My first real report to the team, however, came as the interview schedule was winding down and I had viewed enough videotapes to say anything sensible. Team members were welcoming and open, but my greatest wish was to be cautious - and this, primarily, on two counts: first, I wanted to avoid being the annoying academic who presumes to be a critic of other people's professional practice; second, I wanted to dispel any expectation that what I was doing was social "science." I was careful, then, to preface my discussion of the interviews with disclaimers on both those counts.

Members of the team seemed quite willing to think about the structure of the $\mathrm{AD}$ meetings, particularly the possibility of leading off interviews with something other than information-giving by the physician. We discussed the extent to which positioning the medical information at the beginning of the interview gives primary importance to a medical perspective on the patient (e.g., as opposed to a quality-oflife or a spiritual perspective). We noted too that the knowledge of family members might seem to be more valued if the first matter discussed in the interview was not the medical/psychiatric condition, but, for example, a day in the life of the patient, a matter in which family members are often expert. We noted too, the advantage of opening a dialogue with dialogue, and not what must amount to a monologue. ${ }^{12}$

Team members, too, were interested in matters of the language of the meetings. We discussed the advantages of treatment options being presented in terms of the greatest possible neutrality - so, not "aggressive" treatment opposed to "letting nature take its course," but rather, for example, "if R were to contract pneumonia, would you want her moved to a different ward for intravenous antibiotics?" The change is not a simple one to effect, though. Such specific choices are offered already, as is evident even from the transcript fragments reproduced here - and, in many cases, the more value-laden terms serve an important summary function, clarifying issues of general intention. Team members, then, would be more aware of the rhetorical nature of their terms - and particularly, the special radiance of a term like "aggressive." None of us, however, could suggest any easy solution to problems of terminology.

Terms used by family members were also discussed. On the matter of the mobilization of unexamined terms ("pulling the plug" and so on), team members were interested in taking opportunities to help family members examine their assumptions about end-of-life care and procedures. As the transcripts show, they already do this to some extent. We noted that much popular discourse about the end-of-life comes from television - from shows such as ER and Chicago Hope. That such preconceptions would have a role to play in an AD interview is a matter of some concern and relatively straightforward to address by calling attention to it. 
Family members' imitation of medical discourse (also related to viewing television programs such as $E R$ ) is of some special rhetorical interest, because it provides one way into a question of interpretation. My own first reaction upon noting the tendency among some family members to adopt terms from biomedicine was to see it as evidence of a discursive imbalance of power; so non-medical people would employ medical terms as a way of claiming some kind of authority. But, at Riverview, the clinical team psychologist and principal investigator, Maurice Bloch, saw the same phenomenon differently. According to Bloch, the process of consensual decisionmaking both invites and requires linguistic adjustment by all parties - so family members speak more medically as a means of making contact with their interlocutors while, at the same time, health professionals speak in the ordinary language of experience. In correspondence over the course of research, Bloch wrote:

... the efforts of the clinicians to use everyday language and of the family members to use medical jargon are indicators of the efforts of each to try and reach the other. On one level one may think that as the patient becomes more sophisticated and is able to speak in the language of the physician and as the physician is humanised and comes to speak to the person in his/her (the patient's) own language so the barriers will disappear. But language is only part of the story - a bigger part is for the physician to be in touch with the possibilities of the subjective experience of the patient....

Certainly, Bloch's is a hopeful view of the $\mathrm{AD}$ interview, and a corrective to my outsider's view. While my own account of family members using the language of biomedicine is not necessarily wrong, it does leave out the account from empathy that Bloch provides as a matter of course. (In a similar vein, I have noted what I take to be approval-seeking utterances in family members; Bloch finds that clinical team members, no less than family members, seek approval of their attitudes and actions.) Perhaps, then, one use of the rhetorical critic is that she can, if not correctly interpret, then at least foreground, certain features of discourse, so that there is an opportunity for participants to reflect on their own discourse and the intentions it manages in practice to support.

Further, at my meeting with the clinical team, we discussed the question of whom the interview seeks at any point to assist, and noted the importance of acknowledging when the focus of the clinical gaze moves from the patient whose life and death are being discussed to the family member who is seeking understanding for any choice he or she has made with respect to the patient:

\section{Transcript 4:}


FM Ever since [incident] I have never taken $\mathrm{R}$ out [of the hospital] again .... I want to make it clear, as to the reason why. With me not feeling too too well with these ribs of mine with chronic pain we haven't come down and seen her as much as we'd like to but we talk to her well pretty well every week except for January when we went south there was a spell where we didn't communicate....

Again, the rhetorician acts as a facilitator of a conversation about conversations.

\section{Conclusion}

Rhetoric lives on boundaries and margins, in connections and interstices, and it lives, sometimes as an interloper, in the fields of other people's disciplines - in disciplines like philosophy and anthropology with which rhetoric may share a critical perspective, and disciplines like psychology and medicine, which rhetoric has occupied as an analyst and critic. I have tried for some years as a rhetorician in the realm of medicine to understand the sound of my own voice and I have tried more to do so lately, in the process of thinking about the inter/multi/trans-disciplinarity of the Canadian Institutes of Health Research - and the place of humanities researchers in national health research. I have learned from working on the Riverview project that a rhetorical researcher is a good person to have on an interdisciplinary team and her job might be this: to have a way of seeing, to say what she sees, and to open up a conversation about the meaning of what she saw. Rhetorical study is a part of social action, and social action is itself a rhetorical process.

\section{Notes}

1 This essay grows out of the work of the research and clinical teams whose project it reports. The Principal investigator is Maurice Bloch (Psychologist). Coinvestigators are Baven Pillay (Medical Doctor), Larry Aavisto (Social Worker), Sherri Hayden (Psychologist), Glenn Watts (Chaplain) (and me). My work is in every sense indebted to theirs.

2 Berkenkotter and Ravotas' (1997) work on psychotherapists' "processes of representation" is an excellent example of studying the rhetoric of the human sciences as a rhetoric of genres.

3 Information on CIHR is available at the SSHRC website: $\langle$ http://www.sshrc.ca $\rangle$

4 I am identifying a trend in part by noting the projects of graduate students. Another case in point, then, is the work of Anna Cooper, a doctoral student at University of British Columbia, who recently received funding from the $\mathrm{BC}$ Health Research Foundation to study the rhetoric of genetic counselling. Parson's essay (this volume) is another example of rhetoric of science in the realm of social action. See also Lingard 1998. But I confess to working in very broad strokes to make a case I hope will be suggestive; it is also true, of course, that rhetoric of science internationally includes a great deal of new research directed to social action. (David Martins, for example, a doctoral candidate at Michigan Technologi- 
cal University, has a dissertation in progress that uses rhetorical analysis to study the agency of the person with diabetes.) That, in fact, is why my other general point in this essay is that an important strand of rhetorical analysis is, anywhere, consistent with social action.

5 For discussion of death discourse from a rhetorical perspective, see, for example, Hyde (1993).

6 Where family members granted permission, interviews were videotaped and conversations were transcribed. Not all of the interviews, therefore, were videotaped. The study to date has completed 28 interviews; eight of these were videotaped. Transcriptions were done by Nora Lusterio. The transcription method is based on that of Chenail and Maurice (1995), with minor modifications, since there was no need, for our purposes, to indicate, for example, length of pauses or other fine features of conversation, such as changes in intonation. Note also that in rendering transcriptions here, I have omitted habitual marks of hesitation (e.g., "um"), including only those hesitations or pauses which are needed for clarity because they signal a grammatical shift. Transcripts are numbered; transcript page numbers are noted at the end of passages. Participants are identified as follows:

$\begin{array}{ll}\mathrm{R} & =\text { resident/patient } \\ \mathrm{FM} & =\text { family member (numbered, if necessary) } \\ \mathrm{MD} & =\text { physician } \\ \mathrm{P} & =\text { psychologist } \\ \mathrm{N} & =\text { nurse } \\ \mathrm{SW} & =\text { social worker } \\ \mathrm{C} & =\text { chaplain }\end{array}$

7 See, for example, "Contesting Death, Speaking of Dying ..., Journal of Medical Humanities, forthcoming.

8 See Rhetoric and the Clinic: Discourse, Culture and Medical Practice. Southern Illinois UP, forthcoming. There I note that Klyn (1968), for example, writes that "rhetorical criticism" means only "intelligent writing about works of rhetoric ... in whatever way the critic can manage it" (147); Walter (1968) rejects the notion that "rhetorical theory can furnish a formula" for criticism; Burke (1973), of course, writes that rhetorical criticism is a "naming of manoeuvres," in which the critic is obliged to "use all that is there to use" (p. 23). More recently, rhetorical criticism has become a rubric for a variety of approaches including, according to Foss (1989), Neo-Aristotelian Criticism, Generic Criticism, Feminist Criticism, Metaphoric Criticism, Narrative Criticism, Fantasy-Theme, Pentadic, and Cluster Criticisms; each of these approaches is identified without recourse to algorithm. Algorithm in general, along with programmatic neo-Aristotelianism, is rejected by many contemporary rhetorical critics, as a sometimes uneasy rhetoric roams a postmodern critical field (Leff, for example, renounces his own view of "conventional categories ... as separate and distinct modules to be invoked in methodological order ..." [p. 326].)

9 Brock, Scott, and Chesebro write that "the critical impulse is directed towards some social objective or end.... [1]t seeks to change the human condition" (p. 13).

${ }^{10}$ See, especially, A Grammar of Motives and Language as Symbolic Action. 
11 A note on techne and terminology: I have suppressed in the report of "rhetorical findings" much of a rhetorical lexicon. 1 talk about authority but mention ethos only in passing; I tease out concerns about terms rather than use the Burkean shorthand, terministic screens; I talk about influence, but do not name the rhetorical occasion as deliberative or the rhetoric as hortatory. I was careful to work around a rhetorical vocabulary at first because I had prepared my initial report for an audience not of rhetoricians but of clinicians, and my goal then was to make my observations as available and as useful to my audience as possible. But I want now to make a point of/with this suppression. One feature of interdisciplinary work is that it foregrounds translation problems among disciplinary languages and between disciplinary and nondisciplinary languages. One effect of the sponsoring of research integrativeness by such organizations as the Canadian Institutes of Health Research must be not to erase the boundaries between disciplines but to make them linguistically permeable.

12 Since the videotaped AD interview, though, comes after family members meet with the team psychologist, medical information does not occupy the initial position in the process as a whole, .

\section{References}

Berkenkotter, C. \& Ravotas, R. (1997). Genre as tool in the transmission of practice over time and across professional boundaries. Mind, culture, and activity, 4 , 256-74.

Brock, B.L., Scott, R.L., \& Chesebro, J.W. (1989). Methods of rhetorical criticism. Detroit: Wayne State University Press, 1989.

Burke, K. (1969). A grammar of motives. Berkeley: University of California Press.

Burke, K. (1966). Language as symbolic action. Berkeley: University of California Press.

Burke, K. (1973). Philosophy of literary form, 3rd ed. Berkeley: University of California Press.

Chenail, R. J. \& Morris, G. H. (1995). Introduction. In G.H. Morris \& R. J. Chenail (Eds.), The talk of the clinic: explorations in the analysis of medical and therapeutic discourse, (pp. 1-15). Hillsdale, NJ: Lawrence Erlbaum Associates.

Corbett, E. P. J. (Ed). (1969). Rhetorical analyses of literary works. New York: Oxford University Press.

Foss, S. K. (1989). Rhetorical criticism: exploration and practice. Prospect Heights, Illinois: Waveland.

Fuller, S. (1993). Philosophy, rhetoric, and the end of knowledge. Madison: University of Wisconsin Press. 
Fuller, S. (1997). "Rhetoric of science": double the trouble? In A. Gross \& Wm. Keith (Eds.), Rhetorical hermeneutics: invention and interpretation in the age of science, (pp. 279-98). Albany: State University of New York Press.

Gross, A. \& Keith, Wm. (1997). Rhetorical hermeneutics: invention and interpretation in the age of science. Albany: State University of New York Press.

Hacking, I. (1995). Rewriting the soul: multiple personality and the sciences of memory. Princeton, NJ: Princeton University Press.

Hacking, I. (1998). Mad travelers: reflections on the reality of transient mental illness. Charlottesville, University Press of Virginia.

Harris, R.A. (1990). Assent, dissent, and rhetoric in science. Rhetoric society quarterly, 20, 13-37.

Harris, R.A. (1991) Rhetoric of science. College English 53, 282-307.

Harris, R.A. (1993). Generative semantics and the implosion of ethos. Rhetoric review $23,125-60$.

Hart, R. (1994). Wandering with rhetorical criticism. In W.L. Nothstine, C. Blair, \& G. Copeland (Eds.), Critical questions: invention, creativity, and the criticism of discourse and media, (pp. 71-81). New York: St. Martin's Press.

Hyde, M. (1993). Medicine, rhetoric, and euthanasia: a case study in the workings of a postmodern discourse. Quarterly journal of speech, 79, 201-24.

Klyn, M. (1968). Toward a pluralistic rhetorical criticism. In T. Nilsen (Ed.), Essays in rhetorical criticism, (pp. 146-57). New York: Random House.

Leff, M. (1994). Commentary. In W.L. Nothstine, C. Blair, \& G. Copeland (Eds.), Critical questions: invention, creativity, and the criticism of discourse and media, (pp. 323-27) New York: St. Martin’s Press.

Lingard, L. (1998). Rhetorical ritual of passage: The role of genre acquisition in the socialization of medical students. Unpublished doctoral dissertation. Simon Fraser University.

Molloy, D.W. (1993). Vital choices: life, death and the health care crisis. Toronto: Penguin.

Overington, M. (1977). The scientific community as audience: toward a rhetorical analysis of science. Philosophy and rhetoric, 10, 143-64. 
Paré, A. (1993). Discourse regulations and the production of knowledge. In R. Spilka (Ed.), Writing in the workplace: new research perspectives, (pp. 111-23). Carbondale: Southern Illinois University Press.

Parsons, J. (1999). Pathos, AIDS and public policy: an analysis of The Canadian strategy on HIV/AIDS: moving forward together. Technostyle. This issue.

Polanyi, M. (1958). Personal knowledge: toward a post-critical philosophy. Chicago: University of Chicago Press.

Ryan, C.J. (1996). Betting your life: an argument against certain Advance Directives. Journal of medical ethics, 22, 95-9.

Schryer, C.F. (1993). Records as genre. Written communication, 93, 200-34.

Segal, J.Z. (1993). Writing and medicine: text and context. In R. Spilka (Ed.), Writing in the workplace: new research perspective, (pp. 84-97). Carbondale: Southern Illinois University Press.

Segal, J.Z., Paré, A., Brent, D., \& Vipond, D. (1998). The researcher as missionary: Problems with rhetoric and reform in the disciplines. College composition and communication, 50, 71-90.

Stewart, Larry. (1992). The rise of public science: rhetoric, technology, and natural philosophy in Newtonian Britain, 1660-1750, Cambridge: Cambridge University Press.

Sullivan, D.L. (1993). The epideictic character of rhetorical criticism. Rhetoric review, 11, 339-49.

Vipond, D. (1993). Writing and psychology: understanding writing and its teaching from the perspective of composition studies. Westport, CT: Praeger.

Walter, O. (1968). On the varieties of rhetorical criticism. In T. R. Nilsen (Ed.), Essays on rhetorical criticism, (pp. 158-72). New York: Random House.

Wander, P. C. (1976). The rhetoric of science. Western speech communication, 50, 226-35.

Wander, P. C. (1994). Commentary. In W.L. Nothstine, C. Blair, \& G. Copeland (Eds.), Critical questions: invention, creativity, and the criticism of discourse and media, (pp. 383-88). New York: St. Martin's Press.

Warnick, B. Life in context: What is the critic's role? Quarterly journal of speech, 78, 232-37. 